\title{
Correlation between catalytic activity of supported gold catalysts for carbon monoxide oxidation and metal-oxygen binding energy of the support metal oxides
}

\author{
Takashi Fujita, Masanori Horikawa, Takashi Takei, Toru Murayama, Masatake Haruta* \\ Department of Applied Chemistry, Graduate School of Urban Environmental Sciences, Tokyo Metropolitan University, 1-1 Minami-Osawa, Hachioji, Tokyo \\ 192-0397, Japan
}

\section{A R T I C L E I N F O}

Article history:

Received 20 May 2016

Accepted 4 August 2016

Published 5 October 2016

\section{Keywords:}

Metal oxide-supported gold

nanoparticle catalyst

Support effects

Carbon monoxide oxidation

Volcano-like correlation

Metal-oxygen binding energy

\begin{abstract}
A B S T R A C T
The effect of a wide variety of metal oxide $\left(\mathrm{MO}_{\mathrm{x}}\right)$ supports has been discussed for $\mathrm{CO}$ oxidation on nanoparticulate gold catalysts. By using typical co-precipitation and deposition-precipitation methods and under identical calcination conditions, supported gold catalysts were prepared on a wide variety of $\mathrm{MO}_{x}$ supports, and the temperature for $50 \%$ conversion was measured to qualitatively evaluate the catalytic activities of these simple $\mathrm{MO}_{x}$ and supported Au catalysts. Furthermore, the difference in these temperatures for the simple $\mathrm{MO}_{x}$ compared to the supported Au catalysts is plotted against the metal-oxygen binding energies of the support $\mathrm{MO}_{x}$. A clear volcano-like correlation between the temperature difference and the metal-oxygen binding energies is observed. This correlation suggests that the use of $\mathrm{MO}_{x}$ with appropriate metal-oxygen binding energies (300-500 $\mathrm{kJ} /$ atom 0 ) greatly improves the catalytic activity of $\mathrm{MO}_{x}$ by the deposition of Au NPs.
\end{abstract}

(C) 2016, Dalian Institute of Chemical Physics, Chinese Academy of Sciences. Published by Elsevier B.V. All rights reserved.
Metal oxide $\left(\mathrm{MO}_{x}\right)$-supported Au nanoparticle (NP) catalysts $\left(\mathrm{Au} / \mathrm{MO}_{\mathrm{x}}\right)$ have great potential for environmental purification and green sustainable chemical processes because a lot of $\mathrm{Au} / \mathrm{MO}_{x}$ are active at room temperature, unlike supported palladium or platinum catalysts $[1,2]$. However, the origin of the unique catalytic activity of $\mathrm{Au} / \mathrm{MO}_{x}$ remains unclear because of the complexity of the various physicochemical parameters affecting its catalytic activity. This lack of understanding limits the applications prospects of this promising catalyst.

To simplify this complexity, many researchers have used CO oxidation as a model reaction because of simple reaction stoichiometry. According to their reports, the physicochemical parameters affecting the catalytic activity are the size of the $\mathrm{Au}$ $\mathrm{NPs}$, the interaction between the $\mathrm{Au} \mathrm{NPs}$ and $\mathrm{MO}_{x}$, and the nature of $\mathrm{MO}_{x}$. Among these parameters, the size of the Au NPs $[3,4]$ and the Au NPs- $\mathrm{MO}_{x}$ interaction $[5,6]$ have been relatively well-discussed because they can be tuned by the choice of preparation method and calcination conditions. Specifically, to achieve high CO oxidation activity, the Au NPs should be smaller than $5 \mathrm{~nm}$ and strongly attached to the appropriate $\mathrm{MO}_{x}$. In contrast, the effect of the $\mathrm{MO}_{x}$ support on the catalytic activity of $\mathrm{Au} / \mathrm{MO}_{x}$ is not yet inadequately understood because of the difficulty in systematically comparing a wide variety of $\mathrm{MO}_{x}$. This difficulty can be attributed to two causes. First, in previous studies, a variety of different preparation procedures have been used to obtain $\mathrm{Au} / \mathrm{MO}_{x}$ catalysts to compare. Because the preparation procedures strongly affect the catalytic activity, this hampers a simple comparison of the contributions of $\mathrm{MO}_{x}$ to each $\mathrm{Au} / \mathrm{MO}_{x}$ catalyst. Therefore, to enable a systematic comparison, $\mathrm{Au}$ catalysts supported on a wide variety of $\mathrm{MO}_{x}$ should be prepared using the same preparation method under the same calcination conditions. Co-precipitation and deposi-

\footnotetext{
* Corresponding author. Tel/Fax: +81-42-677-2852; E-mail: haruta-masatake@tmu.ac.jp DOI: 10.1016/S1872-2067(16)62521-4 | http://www.sciencedirect.com/science/journal/18722067 | Chin. J. Catal., Vol. 37 , No. 0, October 2016
} 
tion-precipitation [7] are good candidates because both methods are very common and can easily provide the above mentioned highly active $\mathrm{Au} / \mathrm{MO}_{x}$ catalysts in most cases.

Second, there is limited understanding of the parameters of $\mathrm{MO}_{x}$ that affect the catalytic activity of $\mathrm{Au} / \mathrm{MO}_{x}$. Some researchers have explored the relevance of various parameters of $\mathrm{MO}_{x}$ such as its reducibility [8,9] and oxygen storage capacity [10]. However, there is no general consensus about which parameters affect the catalytic activity, hindering systematic comparisons between different $\mathrm{MO}_{x}$ supports. Therefore, a new parameter of $\mathrm{MO}_{x}$ should be proposed to allow us to conduct such a comparison.

Previously, we proposed that oxygen molecules are activated at the perimeter interface between $\mathrm{Au}$ NPs and $\mathrm{MO}_{x}$ and that the formation of active sites may be related to the presence of oxygen vacancies in the perimeter region [1]. This proposition is strongly supported by several studies investigating $\mathrm{Au} / \mathrm{TiO}_{2}$. First, Widmann et al. [11] reported that lattice oxygen at the perimeter interface of $\mathrm{Au} / \mathrm{TiO}_{2}$ is easily desorbed in $\mathrm{CO}$ atmosphere. Maeda et al. [12] observed oxygen vacancies at the $\mathrm{Au} / \mathrm{TiO}_{2}$ interface during $\mathrm{CO}$ oxidation. Based on these findings, it is reasonable to suggest that the onset of catalytic activity in $\mathrm{Au} / \mathrm{MO}_{x}$ depends critically on the desorption of the lattice oxygen at the perimeter interface induced by the deposition of $\mathrm{Au}$ NPs on $\mathrm{MO}_{x_{*}}$ On the other hand, Saavedra et al. [13] have reported the results of theoretical calculations that oxygen vacancies are not involved in $\mathrm{CO}$ oxidation.

In this communication, we aim to provide new insight into the nature of $\mathrm{MO}_{x}$ in $\mathrm{Au} / \mathrm{MO}_{x}$ systems and to improve their application capability. We prepared Au catalysts supported on a wide variety of $\mathrm{MO}_{x}$ by using co-precipitation and deposition-precipitation techniques under the same calcination conditions. To isolate the contribution of $\mathrm{MO}_{x}$, we measured and compared the catalytic activities of $\mathrm{MO}_{x}$ and $\mathrm{Au} / \mathrm{MO}_{x}$ for $\mathrm{CO}$ oxidation and then discussed the catalytic improvement effect by depositing Au NPs on $\mathrm{MO}_{x}$. To enable a systematic comparison, we introduced the metal-oxygen bonding energy of $\mathrm{MO}_{x}$ $\left(E_{\mathrm{M}-0}\right)$ as an indicator of the ease of lattice oxygen desorption, assuming that $E_{\mathrm{M}-\mathrm{O}}$ is related to the catalytic activity enhancement induced by the deposition of Au NPs on $\mathrm{MO}_{x}$. This hypothesis was inspired by Balandin volcano plots which reflect the Sabatier principle, which states the reaction kinetics can be correlated with thermodynamic properties of heterogeneous catalysts [14].

For this investigation, a variety of $\mathrm{MO}_{x}(\mathrm{M}: \mathrm{Al}, \mathrm{Ti}, \mathrm{Cr}, \mathrm{Mn}, \mathrm{Fe}$, $\mathrm{Co}, \mathrm{Ni}, \mathrm{Cu}, \mathrm{Zn}, \mathrm{Zr}, \mathrm{Nb}, \mathrm{Ru}, \mathrm{Rh}, \mathrm{Pd}, \mathrm{Ag}$, In, La, Ce, Ir, Pt, and Bi) was choosen. This series, which includes most $\mathrm{MO}_{x}$, excludes $\mathrm{SiO}_{2}$, $\mathrm{VO}_{x}, \mathrm{MoO}_{x}$, and $\mathrm{WO}_{x} . \mathrm{SiO}_{2}$ was excluded because its catalytic activity is too low to be measured, while $\mathrm{VO}_{x}, \mathrm{MoO}_{x}$, and $\mathrm{WO}_{x}$ were excluded because of the technical difficulties faced when attempting to deposit Au NPs.

First, $\mathrm{Au}$ NPs supported on various $\mathrm{MO}_{x}\left(\mathrm{Au} / \mathrm{MO}_{x}, \mathrm{M}\right.$ : $\mathrm{Al}, \mathrm{Cr}$, $\mathrm{Fe}, \mathrm{Co}, \mathrm{Ni}, \mathrm{Cu}, \mathrm{Zn}, \mathrm{Zr}, \mathrm{Ru}, \mathrm{Rh}, \mathrm{Pd}, \mathrm{Ag}$, In, La, Ce, Ir, Pt, and Bi) with $\mathrm{Au} / \mathrm{M}$ atomic ratios of 1/19 (Au loading: 6-12 wt\%) were prepared by co-precipitation [7]. To prepare every $\mathrm{Au} / \mathrm{MO}_{x}$ except for $\mathrm{Au} / \mathrm{Ag}_{2} \mathrm{O}$ and $\mathrm{Au} / \mathrm{Bi}_{2} \mathrm{O}_{3}, 200 \mathrm{~mL}$ of a $\mathrm{HAuCl}_{4}(1 \mathrm{mmol})$ aqueous solution was first added to an aqueous solution of
$\mathrm{M}\left(\mathrm{NO}_{3}\right)_{x}$ or $\mathrm{MCl}_{x}(19 \mathrm{mmol})$ and stirred at $343 \mathrm{~K}$. In the preparation of $\mathrm{Au} / \mathrm{Ag}_{2} \mathrm{O}, \mathrm{Au}(\mathrm{OH})_{3}(1 \mathrm{mmol})$ was used as a $\mathrm{Au}$ precursor instead of $\mathrm{HAuCl}_{4}$, and in the preparation of $\mathrm{Au} / \mathrm{Bi}_{2} \mathrm{O}_{3}$, $\mathrm{Bi}\left(\mathrm{NO}_{3}\right)_{3} \cdot 5 \mathrm{H}_{2} \mathrm{O}$ was dissolved in an aqueous solution of nitric acid $(\mathrm{pH}=1)$ to avoid hydrolysis to form basic salt such as $\mathrm{Bi}(\mathrm{OH})_{2} \cdot \mathrm{NO}_{3}$ or $(\mathrm{BiO})_{2}(\mathrm{OH}) \mathrm{NO}_{3}$. Next, each mixture was poured into an aqueous solution of $\mathrm{Na}_{2} \mathrm{CO}_{3}(0.12 \mathrm{~mol} / \mathrm{L}, 200 \mathrm{~mL})$ under vigorous stirring at $343 \mathrm{~K}$, except in the case of $\mathrm{Au} / \mathrm{Bi}_{2} \mathrm{O}_{3}$. For $\mathrm{Au} / \mathrm{Bi}_{2} \mathrm{O}_{3}$, the $\mathrm{Na}_{2} \mathrm{CO}_{3}$ aqueous solution was substituted by a $\mathrm{NaOH}$ aqueous solution (1 mol/L), and the $\mathrm{NaOH}$ aqueous solution was then added until the precipitate was completely formed. All of the precipitates were aged at $343 \mathrm{~K}$ for $1 \mathrm{~h}$ and then washed with distilled water $(313 \mathrm{~K})$ until the $\mathrm{pH}$ of a supernatant stabilized. The filtrated precipitates were dried at $353 \mathrm{~K}$ overnight and then calcined at $573 \mathrm{~K}$ for $4 \mathrm{~h}$ in air $(20$ vol\% $\mathrm{O}_{2}$ in $\mathrm{N}_{2}$; oxidative atmosphere). The $\mathrm{MO}_{x}$ catalysts without gold were also prepared by the same procedure without the addition of the Au precursors.

$\mathrm{Au} / \mathrm{Nb}_{2} \mathrm{O}_{5}$ was prepared by hydrothermal synthesis [15] at a Au/Nb atomic ratio of $1 / 19 . \mathrm{NH}_{4}\left(\mathrm{NbO}\left(\mathrm{C}_{2} \mathrm{O}_{4}\right)_{2}\left(\mathrm{H}_{2} \mathrm{O}\right)_{2}\right)\left(\mathrm{H}_{2} \mathrm{O}\right)_{3}$ (Nb: $6 \mathrm{mmol}$ ) and $\mathrm{Au}(\mathrm{en})_{2} \mathrm{Cl}_{3}(\mathrm{Au}: 6 / 19 \mathrm{mmol}$ ) were added to $40 \mathrm{~mL}$ of water under stirring. The mixture was placed in a Teflon-lined cylindrical autoclave and then heated at $448 \mathrm{~K}$ for $24 \mathrm{~h}$ in air. The solid residue was filtered, washed with water, dried at $353 \mathrm{~K}$, and then calcined at $573 \mathrm{~K}$ for $4 \mathrm{~h}$ in air. $\mathrm{Au} / \mathrm{Nb}_{2} \mathrm{O}_{5}$ was also prepared by deposition-precipitation [7], and calcined at $573 \mathrm{~K}$ for $4 \mathrm{~h}$ in air. $\mathrm{Au}(\mathrm{en})_{2} \mathrm{Cl}_{3}$ was used as a $\mathrm{Au}$ precursor. The gold loading of this catalyst was $1 \mathrm{wt} \% . \mathrm{Nb}_{2} \mathrm{O}_{5}$ was prepared by the same procedure without the addition of the Au precursor.

Some supported $\mathrm{Au}$ catalysts $\left(\mathrm{Au} / \mathrm{MO}_{x}, \mathrm{M}\right.$ : $\mathrm{Al}, \mathrm{Ti}, \mathrm{Mn}, \mathrm{Fe}, \mathrm{Zr}$, and Ce) were provided by Haruta Gold Inc. These catalysts were prepared by deposition-precipitation and had been calcined at $573 \mathrm{~K}$ for $4 \mathrm{~h}$ in air before receipt. The gold loadings of these catalysts were $1 \mathrm{wt} \% . \mathrm{TiO}_{2}$ (Degussa, P25) and $\mathrm{MnO}_{2}$ were purchased from Nippon Aerosil and Chuo Denki, respectively. All the catalysts (prepared and provided) were passed through 120-mesh sieves and pretreated at $523 \mathrm{~K}$ for $1 \mathrm{~h}$ in air before catalytic activity measurements and characterization.

Catalytic activity measurements for CO oxidation were carried out using a U-shaped glass fixed-bed flow reactor. The mass of the catalyst was $150 \mathrm{mg}$, and the reaction temperature ranged from 173 to $700 \mathrm{~K}$. The reactant gas (1\% CO in air) was passed through the catalytic bed at a rate of $50 \mathrm{~mL} / \mathrm{min}$ using a mass flow controller (hourly space velocity of $20000 \mathrm{~h}^{-1} \mathrm{~mL}$ $\mathrm{g}_{\mathrm{cat}^{-}}{ }^{-1}$. The compositions of the effluent gases were determined by gas chromatography (Ohkura Riken model-802 and Shimadzu GC-8A). The moisture content of the reactant gas was monitored by a dew-point meter (Air Liquid DPO-6) and was controlled in the range from 50 to $200 \mathrm{ppm}$. X-ray diffraction (XRD) patterns were recorded with a diffractometer (Rigaku RINT-TTR III) using a $\mathrm{Cu} K_{\alpha}$ radiation operating at $50 \mathrm{kV}$ and $300 \mathrm{~mA}$ over the $2 \theta$ range of $10^{\circ}$ to $70^{\circ}$.

Fig. 1(a) shows the correlation between the $T_{1 / 2}$ values (the temperature for $50 \%$ conversion of $\mathrm{CO}$ in $\mathrm{CO}$ oxidation) of simple $\mathrm{MO}_{x}$ and its standard heat of formation per oxygen atom $\left(-\Delta H_{\mathrm{f}}{ }^{0}\right) . T_{1 / 2}$ was measured in a stream of 1 vol\% CO in air un- 

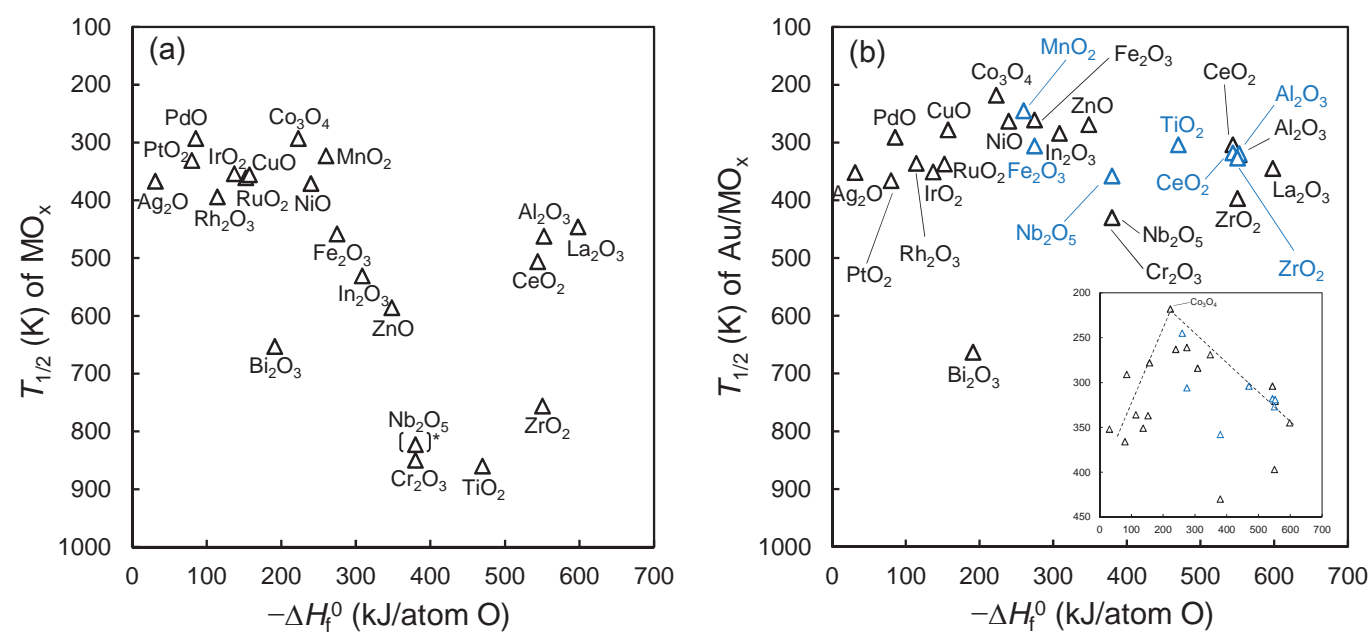

Fig. 1. (a) Correlation between the $\mathrm{CO}$ oxidation activities of $\mathrm{MO}_{x}$ and $-\Delta H_{\mathrm{f}}{ }^{0}$ per atom oxygen. $T_{1 / 2}$ is the temperature for $50 \%$ conversion of $\mathrm{CO}$. ${ }^{*} \mathrm{The}$ temperature required for $7 \% \mathrm{CO}$ conversion on $\mathrm{Nb}_{2} \mathrm{O}_{5}$ is depicted. (b) Correlation between the $\mathrm{CO}$ oxidation activities of $\mathrm{Au} / \mathrm{MO}_{x}$ and $-\Delta H_{\mathrm{f}}^{0}$ per atom oxygen. Black triangles: prepared by co-precipitation. Au/M atomic ratios were 1/19 (Au loading: 6-12 wt\%). Blue triangles: prepared by deposition-precipitation. Au loading: $1 \mathrm{wt} \%$. The catalysts were calcined at $573 \mathrm{~K}$ for $4 \mathrm{~h}$ in air and then pretreated at $523 \mathrm{~K}$ for $1 \mathrm{~h}$ in a stream of $20 \% \mathrm{O}_{2}$ in $\mathrm{N}_{2}$ before catalytic activity measurements. Inset: magnification of the plot for $T_{1 / 2}$ values from 200 to $450 \mathrm{~K}$. Reaction conditions: catalyst 150 mg, reactant gas $1 \mathrm{vol} \% \mathrm{CO}$ in air, flow rate $50 \mathrm{~mL} / \mathrm{min}$, SV $20000 \mathrm{~h}^{-1} \mathrm{~mL} \mathrm{~g}^{-1}$, moisture content 50-200 ppm.

der a space velocity of $20000 \mathrm{~h}^{-1} \mathrm{~mL} \mathrm{~g}^{-1}$. This parameter enables us to compare the catalytic activities of $\mathrm{MO}_{x}$ with widely varying reaction rates. $-\Delta H_{\mathrm{f}}{ }^{0}$ is often used to represent $E_{\mathrm{M}-0}$ [16]. Because the $T_{1 / 2}$ of $\mathrm{Nb}_{2} \mathrm{O}_{5}$ could not be measured in this experiment due to its low catalytic activity, the temperature required for $7 \% \mathrm{CO}$ conversion on $\mathrm{Nb}_{2} \mathrm{O}_{5}$ is depicted in Fig. 1(a). $\mathrm{MO}_{x}$ with $-\Delta H_{\mathrm{f}}{ }^{0}$ values below $220 \mathrm{~kJ} /$ atom 0 exhibited relatively high catalytic activities, except for $\mathrm{Bi}_{2} \mathrm{O}_{3}$, and there was no clear dependence of $T_{1 / 2}$ on $-\Delta H_{\mathrm{f}}{ }^{0}$. Conversely, beyond $220 \mathrm{~kJ}$, a V-shaped correlation between $T_{1 / 2}$ and $-\Delta H_{\mathrm{f}}{ }^{0}$ was observed. The catalytic activities decreased with increasing $-\Delta H_{\mathrm{f}}{ }^{0}$ from 220 to $470 \mathrm{~kJ} /$ atom 0 and increased with an increase in $-\Delta H_{\mathrm{f}}^{0}$ above $470 \mathrm{~kJ} /$ atom 0 .

CO oxidation on certain simple $\mathrm{MO}_{x}$ supports at elevated temperature is often explained by the Mars-van Krevelen mechanism [17]. According to this mechanism, lattice oxygens in the $\mathrm{MO}_{x}$ are consumed in the oxidation reaction. Therefore, we assume that the $-\Delta H_{\mathrm{f}}{ }^{0}$ values of $\mathrm{MO}_{x}$ are related to the catalytic activities of the simple $\mathrm{MO}_{x}$ for $\mathrm{CO}$ oxidation. According to the Sabatier principle [14], volcano dependency is often obtained when plotting the catalytic activity for $\mathrm{CO}$ oxidation on simple $\mathrm{MO}_{x}$ versus $\Delta H_{\mathrm{f}}{ }^{0}$. From this view point, the $-\Delta H_{\mathrm{f}}{ }^{0}$ dependency shown in Fig. 1 can be regarded as a volcano curve as a top of $\mathrm{Co}_{3} \mathrm{O}_{4}$, although $\mathrm{Al}_{2} \mathrm{O}_{3}, \mathrm{CeO}_{2}$, and $\mathrm{La}_{2} \mathrm{O}_{3}$ deviate upward from this curve. In the left side of $\mathrm{Co}_{3} \mathrm{O}_{4}$, incorporation of oxygen was dominant compared to release of oxygen. Therefore, a lot of oxygen vacancies may be formed under reaction condition in the lower $-\Delta H_{\mathrm{f}}{ }^{0}$ region, although we cannot show a direct evidence for amount of oxygen vacancies. Because oxygen vacancies play an important role for oxygen activation $[1,10,11]$, we considered that these $\mathrm{MO}_{x}$ showed relatively higher catalytic activity. On the other hand, in the right side of $\mathrm{Co}_{3} \mathrm{O}_{4}$, release of oxygen was dominant compared to incorporation of oxygen. In this condition, oxygen vacancies may be not formed very much compared to the $\mathrm{MO}_{x}$ with lower $-\Delta H_{\mathrm{f}}{ }^{0}$.
From this reason, we considered that the catalytic activities were decreased with an increase in $-\Delta H_{\mathrm{f}}{ }^{0}$. However, only this consideration cannot explain why $\mathrm{Al}_{2} \mathrm{O}_{3}, \mathrm{CeO}_{2}$, and $\mathrm{La}_{2} \mathrm{O}_{3}$ deviate from the curve.

Fig. 1(b) shows the correlation between $T_{1 / 2}$ and $-\Delta H_{\mathrm{f}}^{0}$ for $\mathrm{Au} / \mathrm{MO}_{x}$. These $\mathrm{Au} / \mathrm{MO}_{x}$ catalysts were prepared by three different preparation methods: co-precipitation (CP, black triangles), deposition-precipitation (DP, blue triangles), and hydrothermal synthesis (HT, black triangles for $\mathrm{Au} / \mathrm{Nb}_{2} \mathrm{O}_{5}$ ). All $\mathrm{Au} / \mathrm{MO}_{x}$ were calcined at $573 \mathrm{~K}$, which is the same calcination condition used for simple $\mathrm{MO}_{x}$. The $\mathrm{Au} / \mathrm{MO}_{x}$ prepared by $\mathrm{CP}$ (Au loading: 6-12 wt\%) were characterized by XRD, and we confirmed that the Au species were deposited as NPs ranging from 4.2 to $10 \mathrm{~nm}$ in diameter on $\mathrm{MO}_{x}$ using the Scherrer equation from a XRD peak attributable to Au crystal plane (200), except for $\mathrm{Au} / \mathrm{PtO}_{2}$ (the peak was not observed) and $\mathrm{Au} / \mathrm{Nb}_{2} \mathrm{O}_{5}$ (66 nm). The $\mathrm{Au} / \mathrm{MO}_{x}$ prepared by DP (Au loading: $1 \mathrm{wt} \%$ ) has been characterized before receipt, and the $\mathrm{Au}$ species were deposited as NPs ranging from 1.8 to $4.5 \mathrm{~nm}$ in diameter on $\mathrm{MO}_{x}$ using a transmission electron microscope (TEM). In these experiments, the difference in the $T_{1 / 2}$ values between the two preparation methods (CP and DP) was $100 \mathrm{~K}$ at a maximum. Fujitani et al. [18] revealed that the reaction rate on $\mathrm{Au} / \mathrm{TiO}_{2}$ was proportional to the perimeter length (below $320 \mathrm{~K}$ ) between Au NPs and $\mathrm{MO}_{x}$ or surface area of Au NPs (above 320 $\mathrm{K})$. We estimated the total perimeter lengths of $\mathrm{Au} / \mathrm{MO}_{x}$ prepared by both $\mathrm{CP}$ and $\mathrm{DP}\left(\mathrm{Au} / \mathrm{Fe}_{2} \mathrm{O}_{3}\right.$ and $\left.\mathrm{Au} / \mathrm{CeO}_{2}\right)$ from loading amount of $\mathrm{Au}$ and mean diameter of Au NPs. As a result, the total perimeter lengths of these catalysts were comparable. Thus, we can conclude that the preparation methods do not strongly affect the correlation between $T_{1 / 2}$ and $-\Delta H_{\mathrm{f}}{ }^{0}$, and comparison of the CP and DP results is reasonable under these experimental conditions. Moreover, we also estimated the total perimeter lengths of some $\mathrm{Au} / \mathrm{MO}_{x}\left(\mathrm{M}: \mathrm{CuO}, \mathrm{Co}_{3} \mathrm{O}_{4}, \mathrm{Fe}_{2} \mathrm{O}_{3}, \mathrm{ZnO}\right.$, and $\mathrm{CeO}_{2}$ ). Although total perimeter lengths of $\mathrm{Au} / \mathrm{CeO}_{2}$ were 
about quarter as long as that of other $\mathrm{Au} / \mathrm{MO}_{x}$, the total perimeter lengths of these catalysts were almost comparable. Therefore, we considered that the result roughly reflects support effects of $\mathrm{MO}_{x}$.

Except for the case of $\mathrm{Au} / \mathrm{Bi}_{2} \mathrm{O}_{3}$, the $T_{1 / 2}$ values of $\mathrm{Au} / \mathrm{MO}_{x}$ were within the range of 200 to $450 \mathrm{~K}$. In this range (Fig. 1(b), inset), a volcano-like tendency with the $\mathrm{Au} / \mathrm{Co}_{3} \mathrm{O}_{4}$ at the top was observed, except in the cases of $\mathrm{Au} / \mathrm{Cr}_{2} \mathrm{O}_{3}$ and $\mathrm{Au} / \mathrm{Nb}_{2} \mathrm{O}_{5}$. The results of $\mathrm{Au} / \mathrm{Cr}_{2} \mathrm{O}_{3}, \mathrm{Au} / \mathrm{Nb}_{2} \mathrm{O}_{5}$, and $\mathrm{Au} / \mathrm{Bi}_{2} \mathrm{O}_{3}$ deviate from this volcano-like tendency. Notably, $\mathrm{Cr}_{2} \mathrm{O}_{3}, \mathrm{Nb}_{2} \mathrm{O}_{5}$, and $\mathrm{Bi}_{2} \mathrm{O}_{3}$ are acidic $\mathrm{MO}_{x}$, and the deposition of $\mathrm{Au}$ NPs on acidic $\mathrm{MO}_{x}$ using a wet process is very difficult technically. Therefore, these catalysts may include very large Au NPs, or the interaction between $\mathrm{Au}$ NPs and $\mathrm{MO}_{x}$ may be very weak. In the future, optimization of the preparation methods for these acidic $\mathrm{MO}_{x}$ is necessary.

Comparison of Fig. 1(a) with Fig. 1(b) indicates that the catalytic activities of $\mathrm{Au}$ NPs supported on noble $\mathrm{MO}_{x}$ are similar to those of noble $\mathrm{MO}_{x}$ alone. In contrast, the deposition of gold on base $\mathrm{MO}_{x}$ markedly enhanced $\mathrm{CO}$ oxidation. Gold catalysts supported on base metal oxides exhibit high catalytic activities for CO oxidation. Our result is thus in good agreement with previous reports. These results suggest that the catalytic improvement induced by deposition of Au NPs is strongly dependent on the type of $\mathrm{MO}_{x}$ used.

To discuss the catalytic improvement, we focus on the difference $\left(\Delta T_{1 / 2}\right)$ between $T_{1 / 2}$ (MOx) and $T_{1 / 2}$ (Au/MOx) as an index of the effect. Fig. 2 shows the correlation between $\Delta T_{1 / 2}$ and $-\Delta H_{\mathrm{f}}{ }^{0}$. The $\Delta T_{1 / 2}$ values of noble $\mathrm{MO}_{x}$ were almost zero, whereas those of base $\mathrm{MO}_{x}$ were positive. This result indicates that catalytically inert simple $\mathrm{MO}_{x}$ were dramatically improved by deposition of $\mathrm{Au}$ NPs. Moreover, these values of base $\mathrm{MO}_{x}$ showed a clear volcano-like tendency, with $\mathrm{TiO}_{2}$ having the highest $\Delta T_{1 / 2}$. According to the above-mentioned discussion about Fig. 1(a), this improvement may be due to formation of oxygen vacancies by deposition of Au NPs.

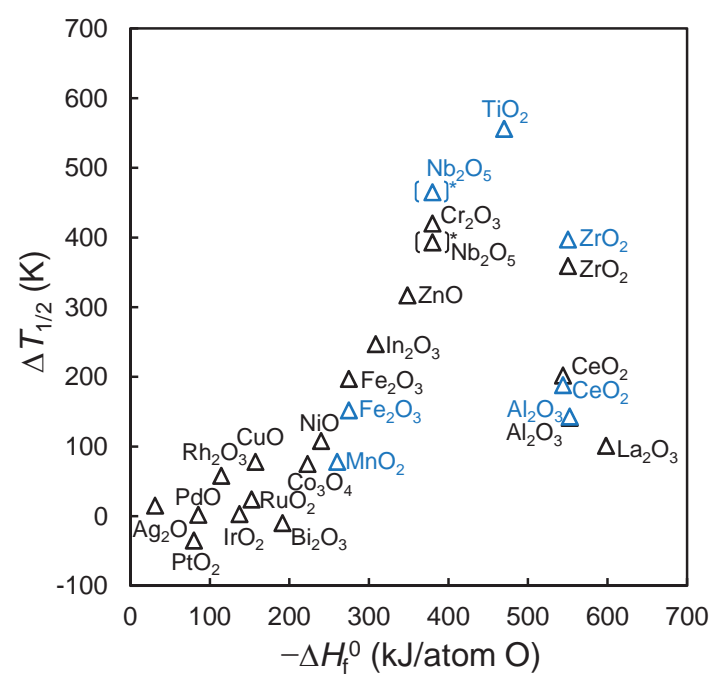

Fig. 2. Correlation between $\Delta T_{1 / 2}$ and M-O bond energy per molar oxygen atom. $\Delta T_{1 / 2}$ is the difference between the $T_{1 / 2}$ values of $\mathrm{Au} / \mathrm{MO}_{x}$ and $\mathrm{MO}_{x}$. Black triangles: $\mathrm{Au} / \mathrm{MO}_{x}$ were prepared by co-precipitation. Blue triangles: $\mathrm{Au} / \mathrm{MO}_{x}$ were prepared by deposition-precipitation. $*$ The temperatures required for $7 \% \mathrm{CO}$ conversion on $\mathrm{Nb}_{2} \mathrm{O}_{5}$ were used instead of $T_{1 / 2}$ values of $\mathrm{Nb}_{2} \mathrm{O}_{5}$.
Based on these results, the $\mathrm{MO}_{x}$ can be preliminary classified by $-\Delta H_{\mathrm{f}}{ }^{0}$ as follows. First, the $\mathrm{MO}_{x}$ with lower $-\Delta H_{\mathrm{f}}{ }^{0}$ values are listed $\left(-\Delta H_{\mathrm{f}} \mathrm{O}<150 \mathrm{~kJ} /\right.$ atom 0$): \mathrm{Ag}_{2} \mathrm{O}, \mathrm{PtO}_{2}, \mathrm{PdO}, \mathrm{Rh}_{2} \mathrm{O}_{3}, \mathrm{IrO}_{2}$, and $\mathrm{RuO}_{2}$. These $\mathrm{MO}_{x}$ do not effectively improve the catalytic activity for CO oxidation by Au NPs deposition, because these

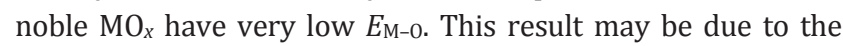
slow incorporation of oxygen from the gas phase to oxygen vacancies. Moreover, we considered that formation of oxygen vacancies by Au NPs deposition may be not effective because lattice oxygens in noble $\mathrm{MO}_{x}$ intrinsically can desorb easily. Second, the $\mathrm{MO}_{x}$ with middle $-\Delta H_{\mathrm{f}}{ }^{0}$ values are listed $\left(-\Delta H_{\mathrm{f}}{ }^{0}=\right.$ 150-500 kJ/atom O): $\mathrm{CuO}, \mathrm{Co}_{3} \mathrm{O}_{4}, \mathrm{NiO}, \mathrm{MnO}_{2}, \mathrm{Fe}_{2} \mathrm{O}_{3}, \mathrm{In}_{2} \mathrm{O}_{3}, \mathrm{ZnO}$, $\mathrm{Cr}_{2} \mathrm{O}_{3}, \mathrm{Nb}_{2} \mathrm{O}_{5}$ and $\mathrm{TiO}_{2}$. These $\mathrm{MO}_{x}$ are effective supports for $\mathrm{Au} / \mathrm{MO}_{x}$, and their effectiveness increases linearly with $-\Delta H_{\mathrm{f}}{ }^{0}$. Consequently, $\mathrm{TiO}_{2}$ is the most effective for improving the catalytic activity for $\mathrm{CO}$ oxidation by Au NPs deposition. This may mean oxygen vacancies effectively form in these $\mathrm{MO}_{x}$ by $\mathrm{Au}$ NPs deposition. Moreover, $\mathrm{ZnO}, \mathrm{Cr}_{2} \mathrm{O}_{3}$, and $\mathrm{Nb}_{2} \mathrm{O}_{5}$ may have great potential for improving the catalytic activity by optimization of the preparation method and pretreatment conditions. Third, the $\mathrm{MO}_{x}$ with higher $-\Delta H_{\mathrm{f}}{ }^{0}$ values are listed $\left(-\Delta H_{\mathrm{f}}{ }^{0}>500\right.$ kJ/atom 0): $\mathrm{CeO}_{2}, \mathrm{ZrO}_{2}, \mathrm{Al}_{2} \mathrm{O}_{3}$, and $\mathrm{La}_{2} \mathrm{O}_{3}$. These $\mathrm{MO}_{x}$ are also effective, but their effectiveness decreases linearly with increasing $-\Delta H_{\mathrm{f}}{ }^{0}$. $\mathrm{Bi}_{2} \mathrm{O}_{3}$ cannot be classified by $-\Delta H_{\mathrm{f}}{ }^{0}$ because of its low $\Delta T_{1 / 2}$ value $(-10 \mathrm{~K})$.

Moreover, some $\mathrm{MO}_{x}$ have unique characteristics. For example, $\mathrm{TiO}_{2}, \mathrm{ZnO}$, and $\mathrm{ZrO}_{2}$ have relatively high oxygen storage capacities. Widmann et al. [9] proposed that the oxygen storage capacity of $\mathrm{MO}_{x}$ was correlated with the catalytic activity of $\mathrm{Au} / \mathrm{MO}_{x}$ for $\mathrm{CO}$ oxidation, demonstrating this correlation for four $\mathrm{MO}_{x}: \mathrm{Au} / \mathrm{TiO}_{2}>\mathrm{Au} / \mathrm{ZrO}_{2}>\mathrm{Au} / \mathrm{ZnO}>\mathrm{Au} / \mathrm{Al}_{2} \mathrm{O}_{3}$. This ordering is also evident in our results for the improvement effect (Fig. 2). In addition, $\mathrm{Cr}_{2} \mathrm{O}_{3}, \mathrm{Nb}_{2} \mathrm{O}_{5}$, and $\mathrm{Bi}_{2} \mathrm{O}_{3}$ are classified in acidic $\mathrm{MO}_{x}$, whereas $\mathrm{La}_{2} \mathrm{O}_{3}$ is classified as basic $\mathrm{MO}_{x}$. The acid-base properties of $\mathrm{MO}_{x}$ may be related to their catalytic activities. However, it is difficult to make this comparison in this study due to the lack of basic $\mathrm{MO}_{x}$ among the investigated catalysts.

To the best of our knowledge, our work provides the first nearly comprehensive comparison of $\mathrm{Au} / \mathrm{MO}_{x}$ catalysts featuring a wide variety of $\mathrm{MO}_{x}$. To perform a systematic comparison, we attempted to standardize the preparation procedure for $\mathrm{Au} / \mathrm{MO}_{\mathrm{x}}$ as much as possible and introduced $E_{\mathrm{M}-\mathrm{O}}$ (represented by $-\Delta H_{\mathrm{f}}{ }^{0}$ ) as a parameter of $\mathrm{MO}_{x}$. A clear volcano-like correlation was observed between $\Delta T_{1 / 2}$ and $-\Delta H_{\mathrm{f}}{ }^{0}$, which suggests that the selection of $\mathrm{MO}_{x}$ with appropriate $-\Delta H_{\mathrm{f}}{ }^{0}(300-500$ $\mathrm{kJ} /$ atom 0 ) greatly improves the catalytic activity induced by the deposition of Au NPs. Furthermore, this clear correlation implies that $E_{\mathrm{M}-0}$ is a good candidate in terms of $\mathrm{MO}_{x}$ parameters that affect the catalytic activity of $\mathrm{Au} / \mathrm{MO}_{x}$, and such thermodynamic parameters are useful for a primary selection of catalyst candidates. The results of this study are expected to improve the application prospects of these catalysts, and we hope that the present systematic comparison will become a technique of choice in future investigations of $\mathrm{MO}_{x}$ in $\mathrm{Au} / \mathrm{MO}_{x}$ catalysts. Moreover, this systematic work is expected to give a useful policy to design appropriate mixed metal oxides as new support materials for dispersed Au NPs. 


\title{
Graphical Abstract
}

Chin. J. Catal., 2016, 37: 1651-1655 doi: 10.1016/S1872-2067(16)62521-4

Correlation between catalytic activity of supported gold catalysts for carbon monoxide oxidation and metal-oxygen binding energy of the support metal oxides

Takashi Fujita, Masanori Horikawa, Takashi Takei, Toru Murayama, Masatake Haruta*

Tokyo Metropolitan University, Japan
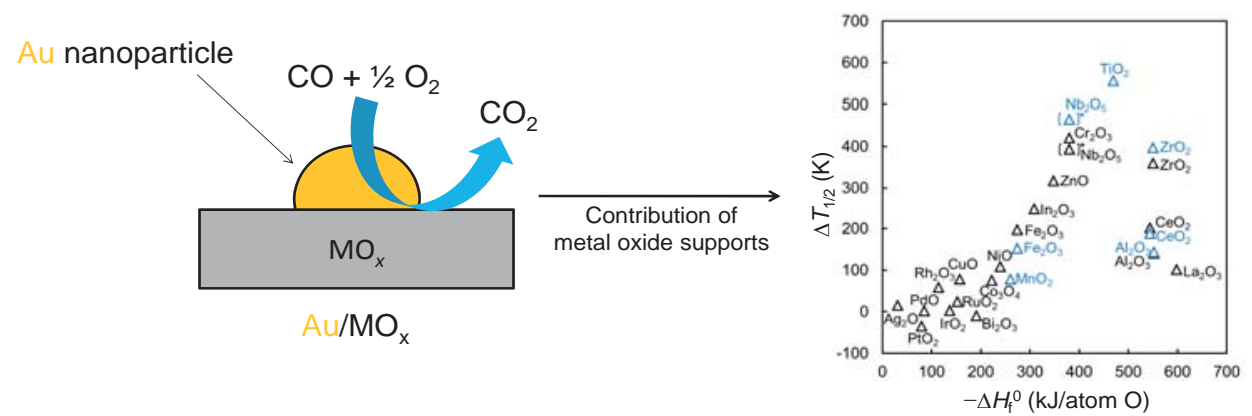

The effects of a wide variety of metal oxide supports in Au catalysts on CO oxidation were evaluated. Clear volcano-like correlation between the effectiveness and the metal-oxygen binding energies was observed.

\section{References}

[1] M. Haruta, Faraday Discuss., 2011, 152, 11-32.

[2] M. Haruta, Angew. Chem. Int. Ed., 2014, 53, 52-56.

[3] S. H. Overbury, V. Schwartz, D. R. Mullins, W. Yan, S. Dai, J. Catal., 2006, 241, 56-65.

[4] I. Laoufi, M. C. Saint-Lager, R. Lazzari, J. Jupille, O. Rabach, S, Garaudée, G. Cabailh, P. Dolle, H. Cruguel, A. Bally, J. Phys. Chem. C, 2011, 115, 4673-4679.

[5] G. R. Bamwenda, S. Tsubota, T. Nakamura, M. Haruta, Catal. Lett., $1997,44,83-87$

[6] X. Y. Liu, M. H. Liu, Y. C. Luo, C. Y. Mou, S. D. Lin, H. K. Cheng, J. M. Chen, J. F. Lee, T. S. Lin, J. Am. Chem. Soc., 2012, 134, 1025110258.

[7] M. Haruta, S. Tsubota, T. Kobayashi, H. Kageyama, M. J. Genet, B. Delmon, J. Catal., 1993, 144, 175-192.

[8] M. M. Schubert, S. Hackenberg, A. C. van Veen, M. Muhler, V. Plzak, R. J. Behm, J. Catal., 2001, 197, 113-122.

[9] Y. Maeda, T. Akita, M. Kohyama, Catal. Lett., 2014, 144, 2086-
2090.

[10] D. Widmann, Y. Liu, F. Schüth, R. J. Behm, J. Catal., 2010, 276, 292-305.

[11] D. Widmann, R. J. Belm, Angew. Chem. Int. Ed., 2011, 50, 1024110245.

[12] Y. Maeda, Y. Iizuka, M. Kohyama, J. Am. Chem. Soc., 2013, 135, 906-909.

[13] J. Saavedra, H. A. Doan, C. J. Pursell, L. C. Grabow, B. D. Chandler, Science, 2014, 345, 1599-1602.

[14] R. A. van Santen, M. Neurock, in: G. Ertl, H. Knoezinger, F. Schueth, J. Weitkamp eds., Handbook of Heterogeneous Catalysis, 2nd ed., Wiley-VCH, Weinheim, 2008, 1415-1445.

[15] T. Murayama, J. Chen, J. Hirata, K. Matsumoto, W. Ueda, Catal. Sci. Technol., 2014, 4, 4250-4257.

[16] M. Haruta, Chem. Rec., 2003, 3, 75-87.

[17] K. Ramesh, L. Chen, F. Chen, Y. Liu, Z. Wang, Y. F. Han, Catal. Today, 2008, 131, 477-482.

[18] T. Fujitani, I. Nakamura, Angew. Chem. Int. Ed., 2011, 50, 1014410147.

\section{负载金催化剂上CO氧化反应活性与金属氧化物载体中金属-氧结合能之间的关系}

\author{
Takashi Fujita, Masanori Horikawa, Takashi Takei, Toru Murayama, Masatake Haruta* \\ 首都大学东京, 城市环境科学研究生院, 应用化学系, 东京192-0397, 日本
}

\begin{abstract}
摘要: 讨论了金属氧化物载体 $\left(\mathrm{MO}_{x}\right)$ 对其负载纳米金催化剂 $\left(\mathrm{Au} / \mathrm{MO}_{x}\right)$ 上 $\mathrm{CO}$ 氧化反应的影响. 采用典型的共沉淀法和沉积沉淀法在完全相同的焙烧条件下制备了一系列 $\mathrm{MO}_{x}$ 负载金催化剂, 以 $\mathrm{CO}$ 氧化转化 $50 \%$ 时的反应温度 $\left(T_{1 / 2}\right)$ 定量评价了 $\mathrm{MO}_{x}$ 载体和 $\mathrm{Au} / \mathrm{MO}_{x}$ 催化剂的催化活性. 进一步将 $\mathrm{MO}_{x}$ 载体与相应 $\mathrm{Au} / \mathrm{MO}_{x}$ 催化剂的 $T_{1 / 2}$ 值之差对 $\mathrm{MO}_{x}$ 载体的金属-氧结合能做曲 线进行关联, 发现二者呈明显的火山型关系. 这一结果表明, 采用具有适当金属-氧结合能(300-500 atom O)的 $\mathrm{MO}_{x}$ 可大大 提高沉积于其上的 $\mathrm{Au}$ 纳米颗粒的催化活性.
\end{abstract}

关键词: 金属氧化物负载金纳米粒子催化剂; 载体效应; 一氧化碳氧化; 火山型关系; 金属-氧结合能

收稿日期: 2016-05-20. 接受日期: 2016-08-04. 出版日期: 2016-10-05.

*通讯联系人. 电话/传真: +81-42-677-2852; 电子信箱: haruta-masatake@tmu.ac.jp

本文的英文电子版由Elsevier出版社在ScienceDirect上出版(http://www.sciencedirect.com/science/journal/18722067). 